REGARDS

SUR LEECONOMIE ALLEMANDE

BULLETIN ECONOMIQUE DU CRAC

\section{Regards sur l'économie allemande}

Bulletin économique du CIRAC

$91 \mid 2009$

Varia

\title{
Salaires conventionnels : une grande diversité
}

Isabelle Bourgeois

\section{OpenEdition}

Journals

Édition électronique

URL : http://journals.openedition.org/rea/3717

DOI : $10.4000 /$ rea.3717

ISBN : 978-2-8218-0878-2

ISSN : 1965-0787

Éditeur

CIRAC

Édition imprimée

Date de publication : 1 mai 2009

Pagination : 84

ISSN : 1156-8992

Référence électronique

Isabelle Bourgeois, "Salaires conventionnels : une grande diversité », Regards sur l'économie allemande [En ligne], 91 | mai 2009, mis en ligne le 01 mai 2011, consulté le 15 septembre 2020. URL : http:// journals.openedition.org/rea/3717

Ce document a été généré automatiquement le 15 septembre 2020

(C) CIRAC 


\title{
Salaires conventionnels : une grande diversité
}

\author{
Isabelle Bourgeois
}

1 En cette période pré-électorale, les revendications d'un salaire minimum légal généralisé se font plus pressantes. Les syndicats du DGB plaident pour un salaire horaire de 7,50€ (ce qui porterait le «SMIC » mensuel à près de $1300 €$ ), voire pour un seuil plancher de $1500 € /$ mois. Si ces exigences étaient couronnées de succès, l'une des conséquences en serait une singulière uniformisation d'un éventail de seuils salariaux conventionnels qui contribue outre-Rhin à la flexibilité du marché du travail, avec, à terme, le risque d'un resserrement vers le bas d'une fourchette des salaires qui s'est révélée étonnamment stable ces dix dernières années. (IB)

\begin{tabular}{|c|c|c|c|c|c|c|}
\hline \multicolumn{7}{|c|}{$\begin{array}{l}\text { Principaux seuils salariaux conventionnels en vigueur en RFA en mars } 2009 \text { (salaires bruts } \\
\text { mensuels, en } € \text { ) }\end{array}$} \\
\hline & \multicolumn{3}{|l|}{2000} & \multicolumn{3}{|l|}{2009} \\
\hline & Bas ${ }^{a)}$ & $\begin{array}{l}\text { Moyen } \\
\text { b) }\end{array}$ & $\begin{array}{l}\text { Haut } \\
\text { c) }\end{array}$ & Bas a) & $\begin{array}{l}\text { Moyen } \\
\text { b) }\end{array}$ & $\begin{array}{l}\text { Haut } \\
\text { c) }\end{array}$ \\
\hline $\begin{array}{l}\text { Secteur privé des transports (Rhénanie du Nord- } \\
\text { Westphal.) }\end{array}$ & 1376 & 1528 & 1582 & 1574 & 1749 & 1810 \\
\hline \multicolumn{7}{|l|}{ Commerce de détail, salariés employés... } \\
\hline dans la production & 1446 & 1616 & 1939 & 1649 & 1841 & 2209 \\
\hline dans l'administration & 1082 & 1240 & 2224 & 1235 & 1622 & 2533 \\
\hline \multicolumn{7}{|l|}{ Imprimerie (ouest), salariés employés... } \\
\hline dans la production & 1659 & 1971 & 2489 & 1928 & 2209 & 2891 \\
\hline
\end{tabular}




\begin{tabular}{|c|c|c|c|c|c|c|}
\hline dans l'administration & 1323 & 1514 & 3884 & 1537 & 1760 & 4515 \\
\hline \multicolumn{7}{|l|}{ BTP (ouest), salariés employés... } \\
\hline dans la production & 1629 & 2134 & 2672 & 1853 & 2457 & 3081 \\
\hline dans l'administration & 1166 & 1678 & 3682 & 1724 & 1989 & 4866 \\
\hline Coiffure (Rhénanie du Nord-Westphal.) & 754 & 1075 & 1932 & 1300 & 1703 & 2163 \\
\hline Banque (RFA) & 1567 & 1776 & 3075 & 1853 & 2102 & 3637 \\
\hline Propreté (secteur privé ; RFA) & 1428 & 1785 & 2856 & 1685 & 2093 & 3317 \\
\hline Hôtellerie/gastronomie (Bavière) & 1127 & 1519 & 2316 & 1313 & 1771 & 2699 \\
\hline $\begin{array}{l}\text { Entretien automobile (Rhénanie du Nord- } \\
\text { Westphal.) }\end{array}$ & 1008 & 1571 & 2088 & 1556 & 1765 & 3244 \\
\hline \multicolumn{7}{|l|}{$\begin{array}{l}\text { Industrie des métaux (Bavière), salariés } \\
\text { employés... }\end{array}$} \\
\hline dans la production & 1379 & 1664 & 2213 & 1836 & 2342 & 4271 \\
\hline dans l'administration & 1165 & 1632 & 3346 & 1836 & 2342 & 4271 \\
\hline Chimie (Rhénanie du Nord) & 1668 & 1953 & 4004 & 2034 & 2381 & 4765 \\
\hline \multicolumn{7}{|l|}{$\begin{array}{l}\text { Fonction publique communale (ouest), salariés } \\
\text { employés... }\end{array}$} \\
\hline dans la production & 1492 & 1702 & 2121 & 1416 & 1842 & 3639 \\
\hline dans l'administration & 1411 & 1570 & 3308 & 1416 & 1842 & 3639 \\
\hline
\end{tabular}

Source des données : IWD, n 15/2009, NRW-Tarifregister, WSI-Tarifarchiv. a) salariés non qualifiés ; b) formation professionnelle achevée ; c) qualification supérieure.

\section{INDEX}

Mots-clés : salaire, revenu, salaire minimum, syndicat, négociation collective, convention collective, partenaires sociaux 